\title{
RESEARCH OF CULTURAL TOURISM AND REGIONAL GASTRONOMY IN THE TOURIST REGION OF NORTHERN MORAVIA AND SILESIA
}

\author{
[Výzkum kulturního cestovního ruchu a regionální gastronomie v turistickém \\ regionu severní Moravy a Slezska]
}

\author{
Tat’ána Karásková ${ }^{1}$, Alena Zedková ${ }^{2}$ \\ ${ }^{1}$ Slezská univerzita, Obchodně podnikatelská fakulta, Univerzitní nám. 1934/3,733 40 Karviná \\ Email:karaskova@opf.slu.cz \\ ${ }^{2}$ Slezská univerzita, Obchodně podnikatelská fakulta, Univerzitní nám. 1934/3,733 40 Karviná \\ Email:zedkova@opf.slu.cz
}

\begin{abstract}
The paper deals with the primary research which is focused on visitors of the tourist region of Northern Moravia and Silesia and which was carried out in the autumn months of the year 2013. The main objective of the paper is proving the mutual relation of cultural tourism and regional gastronomy in the area of the Moravian-Silesian Region by the method of the questionnaire survey and the mathematical-statistical method in the mutual dependence of cultural tourism and regional gastronomy in the above mentioned area. The introductory part deals with the theoretical base of the stated issues. Subsequently objectives and hypotheses of the research are presented and results of the research are described. The final synthesis of discovered data specifies focusing on interests of potential visitors which will serve to increasing and improving the quality of the portfolio of requested services for participants engaged in the development of tourism in the researched locality.
\end{abstract}

Keywords: analysis, culture, empirical research, heritage, method, tourism.

JEL classification: L66, L83

Doručeno redakci: 7.1.2014; Recenzováno: 20.6.2014; 4.8.2014; Schváleno k publikování: 11.2.2015

\section{Introduction}

Culture is one of the fundamental phenomena which are connected with the creation of man. Since the beginning of the existence of mankind up to present times specific cultural manifestation has been characteristic for different groups of people living in various geographical areas. As the society was developing, culture was developing together with it as well. Culture, and especially religion, has become one of the main motives for travelling (later tourism), already in times when the first ancient civilisations appeared on the Earth. There exist different opinions on culture. The term culture can be understood as e.g. the sum of spiritual and material values, created in the course of the development of the human society, the set of information, scientism, the stage of education and all other features of the environment which characterize the certain social group whose members take over culture as the common intellectual and emotional heritage, the sum of activities and products of human skill and aptitude of all times and all areas in the world, the process arising from human skill and aptitude which follows satisfaction and development of rational and emotional needs of man (Kmeco, 2006, p. 5).

And it is exactly culture and cultural reasons which markedly motivate the mankind to travel. Cultural tourists are led by the desire to experience something extraordinary, the possibility to get to known new areas and their population, the way of their life, as well as to know also art, history and culture. At their travels tourists then show the certain need of self-realisation. The connection of travelling and learning culture and all its aspects is represented by one of the 
forms of tourism, and that is cultural tourist industry. Participants of cultural tourism are motivated for travelling by getting to know cultural historical sights and monuments, art, culture, traditions and customs of people living in the visited destination. Cultural tourism can have the form of visiting museums, galleries, exhibitions, cultural historical monuments, archaeological sites, music or film festivals, social, folklore and religious events. It requires willingness of visitors to learn something new, it thus combines the elements of education, entertainment and spending leisure time. It participates in increasing the social, cultural and professional level of people. There often occurs its penetration into other forms of tourism, especially spa, recreational, health and congress tourism (Hesková, 2011). It can be the kind of filling of other forms of tourism, though it is not the main motive for the travel. Cultural tourism is often connected with the visit of the cultural destination, which is such destination in the offer of which culture appears significantly or dominates. Cultural destinations can be both single establishments (museums, galleries, historical monuments, open-air folk museums or particular exhibitions) and whole regions, towns and communities on whose territory visited historical monuments, museums, the cultural landscape and other cultural attractive places and events are located. The cultural landscape, towns, cities and manor houses, cultural monuments, museums, galleries, collections, programme orientated centres (educative entertaining centres) and cultural events are significant cultural sources and at the same time general types of cultural destinations (Kesner, 2005).

From the theoretical viewpoint getting to know art, cultural monuments, preserved sights of the particular destination, completed by the offer of traditional regional food and products produced by the original traditional recipes can intensify the final product in a significant way by mutual cooperation of outputs from researched fields. One of the consequences of the global market there is a higher accessibility of miscellaneous food from all corners of the world. This fact has caused also among others that food has started to be talked more in the media in connection with travelling and by that also the popularity of this theme is growing. Local food or local specialities thus have become one of the main attractions for tourists who often seek real and authentic experiences related to food (Shenoy 2005; Nummedal and Hall 2006).

The regional food in connection with tourism offers the possibility how to know the local cultural heritage by means of consumption. At the same time it provides by the ideal concept the fresh and quality meal to tourists (in reality this idea is more likely disputable), mainly, however, it can represent the principal tool of the development of tourism thanks to the support of local producers and gastronomic services.

In connection with local food authenticity is created by factors as it is the historical link, time, the place and craftsmanship. Themes as the historical context and interconnection with the place can be found in case of the category of tradition: food as the result of the historical development within scope of the given locality. Its origin precedes industrially processed food and this contrast co-creates its values (Pratt, 2007).

Zuzana Vlasatá - Geryková (2009) writes about authenticity as about the dimension of preciousness and exclusivity and connects authenticity with limitedness of the natural source and defence against imitations and substitutes in gastronomy. Authenticity can be perceived by terms as genuineness and uniqueness. It is the concept which marks something that is original and indigenous - that is the way of limitation and differentiation which brings with it at the same time the certain cultural capital. 
Jeff Pratt (2007) compares the delaminating character of local culture (in the form of the relation between the people, the place, their knowledge and meal) in distinctive cases with exaggerating of nationalism and agrees with Melanie DuPuis and David Goodman (2005) that celebration of traditions, culture and the origin functions as the nutrient soil for strengthening "patriotic and anti-migration" attitudes.

For the term authenticity there is also an inherent evaluating measure. It is in a certain way one of the possibilities how to mark the certain quality of the given goods. In the context of the local food authenticity is evaluated also by means of the same characteristics as the quality. These characteristics mean the emphasis on the origin of food, the way how it was produced, what from and who by. There are more emphasising aspects, certain marks which in the same way as at the quality support values which have not only the cultural background, but also the market dimension.

It is commodification of attributes which are in the certain context natural and not lacking cultural historical importance, but they acquire its importance by their exclusivity, uniqueness or authenticity just in the contrast to consumer goods (without those "natural" attributes) which are the product of the modern world.

"Authenticity is not the remnant of some simple rural life, but just the shade cast by economy functioning on the base of market exchange" (Pratt, 2007, p. 295). In the final consequence then authenticity gains importance for those who perceive the given local food as an exotic matter.

The local traditional meal - the regional meal in connection with tourism offers the possibility how to learn the local cultural heritage by means of consumption. At the same time it provides according to the ideal ideas fresh and quality meal to tourists (in reality this idea is more likely disputable), mainly, however, it can represent the main tool of tourism thanks to the support of local producers and gastronomic services. According to authors Yurtseven and Kaya (2011) and Rebecca Sims (2009) the local food is therefore an important potential source ensuring economic, cultural and environmental sustainability of interesting destinations for tourists.

According to Kmeco (2006) the way of living belongs to the summary of activities and products of human skills and aptitude. For the concept of gastronomy the famous aphorism of Brillat-Savarin is the base: "Animals gorge and man eats. Only man of spirit as the only one can eat".

In its meaning the quotation helps grasp the position of gastronomy in relation to nutrition, food and cooking: Holub (2004) approaches to gastronomy as to one of the most important signs of culture, as the phenomena which all history of mankind is reflected peculiarly and sharply in. In many religions and numerous societies there are many prohibitions and orders imposing what to eat and drink that come out from ritual, social, sexual and nutritious reasons. The aim of cooking procedures in preparing and presenting prepared foodstuff is to make it good for eating in the given social conditions. The relation of man to foodstuff has anyway a strongly emotional character, as the basic foodstuff is connected with ecological niche and its cultural evaluation is a symbol of everyday certainty. In industrial societies the claim on endless diversity of relations of human communities to their food is hardly sustainable. Therefore in minority communities food of symbolic importance is prepared constantly from basic foodstuff around which nostalgic emigrants gather regularly. Preferring 
the certain way or combination of heat food preparations in succession on the conditions of social, economic and cultural character then leads to differentiation of cuisines - local, regional and national ones.

\section{The objective of the paper and methods}

The paper presents the analysis of the relation of cultural tourism and regional gastronomy in the tourist region of Northern Moravia and Silesia (the Moravian-Silesian Region). The main objective of the paper is to present the influence of cultural tourism and regional gastronomy on the development of tourism in the Moravian-Silesian Region. The paper demonstrates the empiric research in the course of the months October and November 2013 in the tourist region of Northern Moravia and Silesia. The first partial objective of the paper is to verify the hypothesis whether there is a positive relation between the number of cultural monuments in the region and the number of restaurants which offer traditional gastronomy. The second partial objective of the paper is to present preparation, procedure, and mechanism of compounding, implementation, evaluation and proposals of the authors on increasing competitiveness of the region in the sphere of tourism.

At implementation of the research there were used two methods of data collection. A guided, partially structured dialogue in case of the advance research and further the questionnaire survey in the given locality.

At processing the results of the research there were used theoretical methods of analysis at analyzing the text of the source material and the source data of the primary empiric research in the terrain; further induction, deduction, the method of synthesis and generalisation at formulating conclusions. Relational dependencies were investigated by means of the mathematical-statistical method of correlation (mutual dependencies of cultural tourism and regional gastronomy). Correlation analysis is used for explaining the dependence between the data in cases when there are at disposal accidental quantities at which it is not possible to determine beforehand which of them are dependent and which are independent variables.

\section{Addressing the target group of respondents}

At preparing of the research itself at first there was realized the trial questionnaire survey (pilot survey), the aim of which was to make clear the research purpose to the respondents, to gain their opinion on its importance, especially on the evaluation of cultural motives in connection with gastronomic elements of the region and verification of the suitability of the final form of the questionnaire. The pursuit was to obtain the date of visitors both from the accommodation facilities, information centres and cultural institutions.

In the final phase of preparation of the research there was organized a meeting with students of the Department of tourism of the study programme Hotel Industry and Economy of Tourism of the Silesian University in Opava, School of Business Administration in Karviná. At this training of interviewers, students were given instructions and orders for due filling of questionnaires by respondents. Students then offered to tourists the questionnaires to fill in various localities of the Moravian-Silesian Region. The part of the due course of the survey confirmation of filled in forms was done directly in the cooperating establishments.

\section{The course of the research}

The empiric research was done in October and November 2013 with the assistance of students of the Department of tourism of the study programme Hotel Industry and Economy of Tourism of the Silesian University in Opava, School of Business Administration in Karviná in 
various localities of the Moravian-Silesian Region. Within the special working experience and private working experience students participated in the questionnaire survey in restaurant and accommodation establishments in Karviná and surroundings, Ostrava, Havírov, Bílovec, Dětmarovice, Dolní Lomná, Hukvaldy and others. Together 15 establishments of the searched issues were addressed. The advantage of such carried out empiric research was the quick collection of data and low costs related to that. In the second phase of the research 400 questionnaires were distributed and after the elimination of unsatisfactory questionnaires 345 were evaluated. Eliminated questionnaires were incompletely filled or contained inaccuracies, which in the final phase would misrepresent the final data.

\subsection{Research tools}

Regarding the way of distribution and the whole directing of the research more likely to the explorative direction the emphasis was placed on the broader content part. To characterize the sample only fundamental segmentation criteria were used exploited at studying the influence of environment on preferences of visitors.

To test hypotheses and to fulfil the objective of this paper the primary empiric research was carried out by the form of the dialogue, the questionnaire survey and the mathematicalstatistical methods of correlation. The questionnaire was structured in the way that in the first part there was found out information on the region from which respondents have come to the given localities. Further, the reason of arrival and the attractiveness of the locality, etc. were investigated. Respondents then filled in the length, the price and the kind of accommodation facilities during the stay. The most sizeable part was made by a detailed table with listed cultural and gastronomic elements and motives for travelling to the given region. The final part of the questionnaire was formed by the information about respondents.

Within the survey following aims were determined:

- To identify the extent of perception of attractiveness of the Moravian-Silesian Region for tourism.

- To identify visitors' awareness of the region and the tourist area about the assortment offer of the regional specialities in restaurant facilities.

- To identify the extent of interests in cultural elements as motives for travelling to the Moravian-Silesian Region.

- To verify hypotheses on the fact whether there exists the positive relation between the number of cultural monuments in the region and the number of restaurants, which offer traditional gastronomy.

\subsection{Defining hypotheses}

The hypothesis is the statement expressed by the indicative sentence which can be confirmed or disproved. According to Malátek (2001, p. 100) the hypothesis expresses a certain scientific presumption (opinion) on the structure and development of social objects (or phenomena), on the character of elements and relations which these objects (phenomena) creates and on the mechanism of their impact and development. The significant function of hypotheses is interconnection of the theoretical and empiric element of work.

When preparing the research we proceeded from the presumption that the interest in culture, art and cultural heritage goes hand in hand with the interest in regional gastronomy and tourists will perceive this connection strongly like this. Therefore we set following hypotheses: 
H1: More than $60 \%$ of respondents during their holidays/trips show "strong" up to "maximal" interest in traditional cultural destinations such as stately homes and feudal monuments (castles, chateaux, remains, etc.), museums and galleries and with regard to the character of monuments in the region also technical monuments.

$\mathrm{H} 2$ : More than $60 \%$ of respondents would appreciate the regional speciality in the menu card of restaurants in the place of their stay

H3: More than $60 \%$ of respondents consider the Moravian-Silesian Region to be a destination attractive for tourism.

Relational dependencies were investigated by means of the mathematical-statistical methods of correlation (the mutual dependence of cultural tourism and regional gastronomy) in the above mentioned localities. We proceeded from the presumption that destinations with a higher number of sightseeing places on their territory are more attractive for cultural tourists and those in which territory there are fewer monuments made accessible are less attractive. Further it can be presumed that more attractive cultural destinations will be disposed of higher gastronomic facilities which specialize in the offer of typical regional meals as we already know traditional gastronomy is an important part of the culture of the region. For this reason we have set the following hypotheses. For their verification we have decided to use the method of the correlation analysis.

$\mathrm{H}$ 4: Between the number of real estate monuments registered in the Official List of Cultural Monuments of the Czech Republic in particular tourist areas of the tourist region of Northern Moravia and Silesia and the number of accessible monumental sights, museums and galleries in these areas there exists the positive statistical dependence.

$\mathrm{H}$ 5: Between the number of the publicly accessible sights, museums and galleries and the number of certified restaurant establishments of the project of Czech Specials in particular tourist areas of the tourist regions of Northern Moravia and Silesia there exists the positive statistical dependence.

\section{Results of the research and discussion}

In total there were evaluated 400 questionnaires from which 55 did not comply with conditions of the completely filled in questionnaires, or there occurred imperfections of another kind. After their elimination there were left 345 questionnaires for the final evaluation.

\subsection{Collection and evaluation of the data}

In the answer as for the region of the origin of respondents coming to the tourist region of Northern Moravia and Silesia (the Moravian-Silesian Region) the highest number of tourists $48.82 \%$ came from the Moravian-Silesian Region, $17.92 \%$ respondents came from the Slovak Republic and then $12.43 \%$ of respondents from the Zlín Region. As far as on the fourth place respondents from the Olomouc Region were placed with $7.51 \%$ and tourists from the South Moravian Region formed the proportion of $5.78 \%$. The smallest number of tourists $-0.29 \%$ came from the Ústecký and Královéhradecký Region. From the point of relation of the population to the tourist region the population from the Moravian-Silesian Region can be considered "the local patriots". As the possible reason it can also be the fact of lower purchasing power of the population of the Moravian-Silesian Region, but also more costly accessibility of localities with the higher activity in tourism. 
Prevailing reasons for the visit to the Moravian-Silesian Region as the other was specified in the questionnaire by $16.99 \%$ of the respondents, the interest in hiking and sport was confirmed by $16.60 \%$, seeing the places by $12.11 \%$ of the respondents, and because of work and visit of relatives $11.33 \%$ of the respondents travel to this region. Natural conditions, springing mountain waters and extraordinarily favourable mountain climate with clean air offering the stimulus for relaxation and wellness were also marked by $11.33 \%$ of the respondents.

From the aspect of activities in the region as the best in the Moravian-Silesian Region it is evaluated entertainment and social life by $17.38 \%$, followed by hiking with $13.40 \%$ and visits of cultural events with $12.28 \%$ and sightseeing tourism with $9.57 \%$.

The length of stay in the Moravian-Silesian Region represented in $35.59 \%$ accommodation longer than 7 nights, despite the fact that the research in this locality was carried out in autumn months. It was followed by the proportion of $27.06 \%$ of the respondents with 3 to 7 nights and $25.29 \%$ decided for 1 to 2 nights. The smallest proportion of tourists $(12.06 \%)$ decided for the one-day stay.

In the prevailing majority $-47.73 \%$ they travel to the given locality by car which is definitely the most convenient means of transport. Public means of transport to visit Northern Moravia were used by $40.06 \%$, and that is even in spite of the fact that public transport especially in the area of the Jeseník disposes of an insufficient net of traffic service, whether it is bus or railway transport. In Northern Moravia the proportion of $6.53 \%$ of tourists go on foot and transport by bikes is used by $3.98 \%$.

Who does the potential tourist travel with? As for this question there was shown in $28.85 \%$ in Northern Moravia that tourists choose friends for the visit of the region as their companions and only after that they choose a partner $(26,33 \%)$ and family members $(20.73 \%)$ or they travel completely by themselves, without a partner (20.45\%). In a bigger extent than it was in the past tourists - single ${ }^{1}$ (Stein, 1976) travel alone for sightseeing.

High quality accommodation was preferred by the majority of addressed tourists $(17.31 \%)$, that is in a three-star hotel and more and a guesthouse was chosen by $16.21 \%$. From that it is obvious that tourists choose the quality accommodation for spending their leisure time and generally require also high standard quality of catering services, which is in the state-wide scale at the economically weaker regions evidently interesting information. Compared to that there exists a segment of respondents who consider the accommodation to be a more secondary service at spending leisure time and they give preference to other types of accommodation (13.19\%), or they make use of accommodation in private $(13.46 \%)$ and they transfer their demands into the sphere diametrically different. The visit without accommodation was chosen by $12.91 \%$.

\footnotetext{
${ }^{1}$ The Czech language for the present does not have a corresponding Czech equivalent for the English term singles, it could be translated as not engaged or living alone. Sociologist Možný uses the term "voluntary unpaired". As singles there are usually persons between 25 up to 40 years, living without the steady partner whose basic feature is successfulness at work and desire to build their own carrier. They devote all time to work or their interests. This phenomenon is much more spread in bigger towns. The author of typology which is concentrated on distinction whether the life style of a person living single is the voluntary alternative or not and whether it is the alternative temporary or stable is an American psychologist Petr J. Stein.
} 
For choosing their holiday tourists used a whole range of sources. The majority of tourists in Northern Moravia and Silesia by the proportion of $54.65 \%$ solves the choice of holiday via the Internet which is presently the quite common source of searching.

Table 1: Information sources for the choice of holiday

\begin{tabular}{|l|r|r|}
\hline \multicolumn{3}{|c|}{ Northern Moravia and Silesia } \\
\hline Information sources for the choice of the holiday & \multicolumn{1}{|c|}{ Absolutely } & Relatively in \% \\
\hline Internet & 235 & $54.65 \%$ \\
\hline Press & 21 & $4.88 \%$ \\
\hline Radio & 10 & $2.33 \%$ \\
\hline Television & 24 & $5.58 \%$ \\
\hline Tourist Information Centre & 24 & $5.58 \%$ \\
\hline Recommendation of the family, friends, etc. & 85 & $19.77 \%$ \\
\hline I went on ,,blind“ & 11 & $2.56 \%$ \\
\hline Tour operator, travel agency & 12 & $2.79 \%$ \\
\hline Other (not stated ) & 8 & $1.86 \%$ \\
\hline Altogether & 430 & $100.00 \%$ \\
\hline
\end{tabular}

Source: own processing, 2013

The indispensable source with more communicative approach is chosen by tourists who are not satisfied with passive receiving of the information from the Internet. This group of tourists $-14.77 \%$ chooses a tourist information centre with the possibility of obtaining further detailed information. The way of acquiring sources of information from the family circle, friends, acquaintances or colleagues was chosen by $12.08 \%$ of tourists and the television commercials or sources of information acquired from telecasting was stated by $5.37 \%$.

Aspect of expenses per person per day of the stay is presented by the graph which shows the daily financial expenses per one tourist.

Figure 1: Financial expenses per person per day

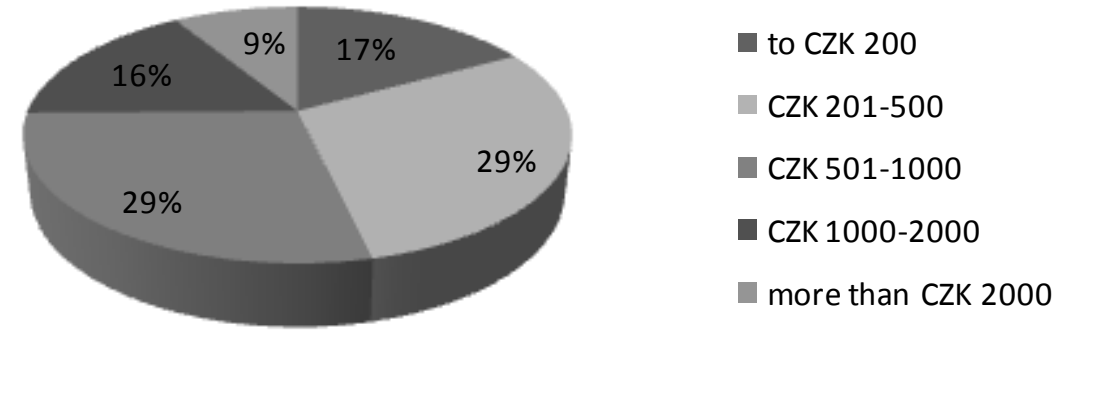

Source: own processing, 2013

$29 \%$ of tourists spent the financial amount from CZK 201 to CZK 500 and the same proportion of tourists is willing to pay CZK 500 to CZK 1,000. The lowest financial expenses to CZK 200 are spent by $17 \%$ tourists and a higher amount that is from CZK 1,000 to CZK 2,000 can be afforded by $16 \%$ tourists, which at presented low purchasing power in the region is surprising. More than CZK 2,000 is spent by $8.8 \%$ of tourists.

The next part of the questionnaire presents the scale of evaluation of cultural motives. The average interest in history of the visited area and customs and traditions was shown by 
103 respondents $(30.12 \%)$ resp. 118 tourists $(34.30 \%)$ and the strong interest by 71 $(24.76 \%)$ resp. $77(22.38 \%)$ tourists.

Figure 2: Level of tourists' interest in the history of the visited region

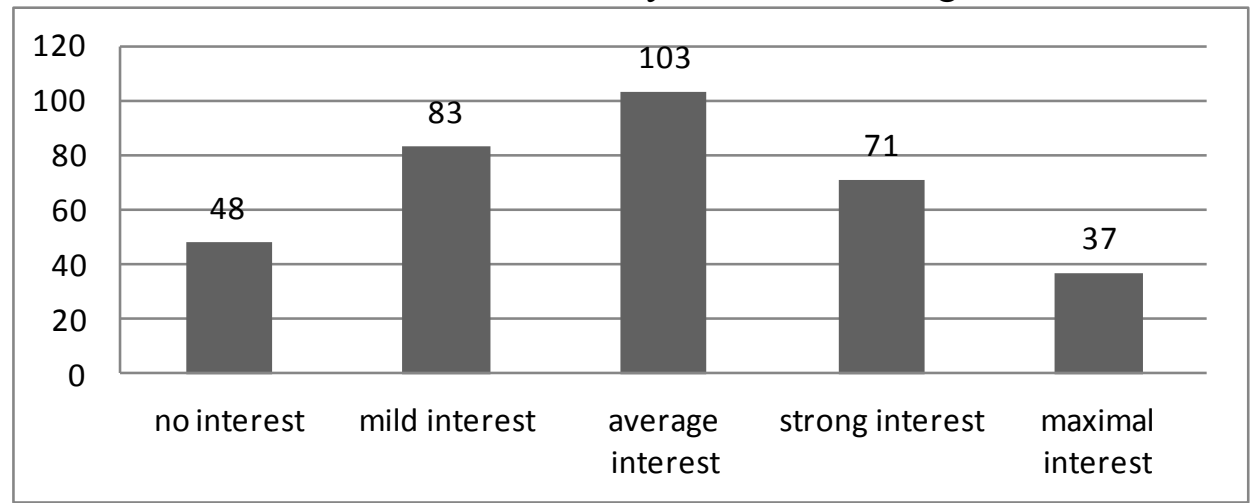

Source: own processing, 2013

Figure 3: Level of tourists' interest in the customs and tradition in the visited region

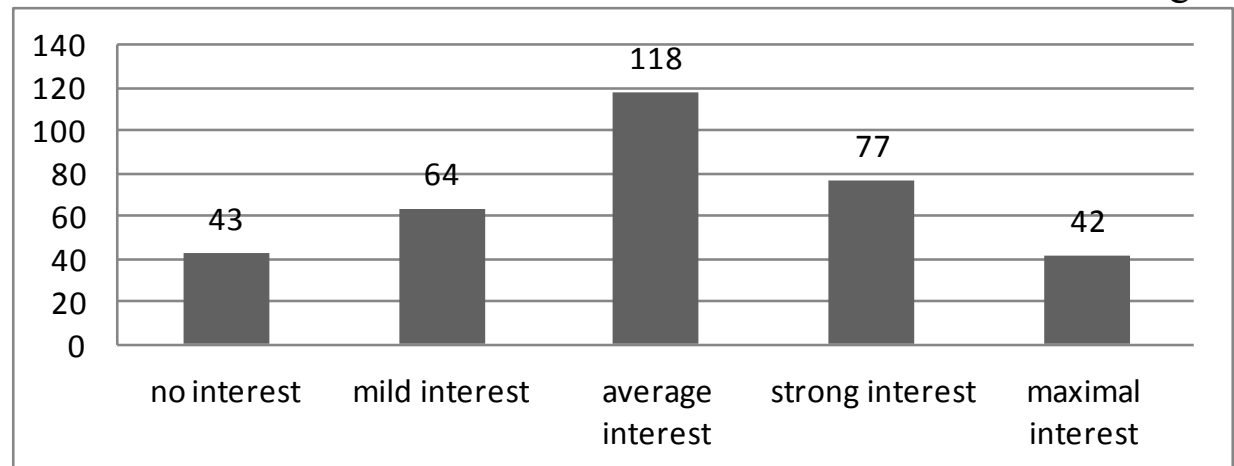

Source: own processing, 2013

From the graphs it is evident that customs and traditions (e.g. the carnival, building the maypole, traditional Christmas customs, etc.) do not have so deep roots in the historical context of the tourist region of Northern Moravia and Silesia as in more south situated localities of the Czech Republic.

Folk architecture in the form of rural monumental reservations, open-air folk museums and rural buildings is partly interesting for 221 tourists. However, the largest number of tourists $110(32.16 \%)$ has only average interest in it.

Figure 4: Level of tourists' interest in the folk architecture in the visited region

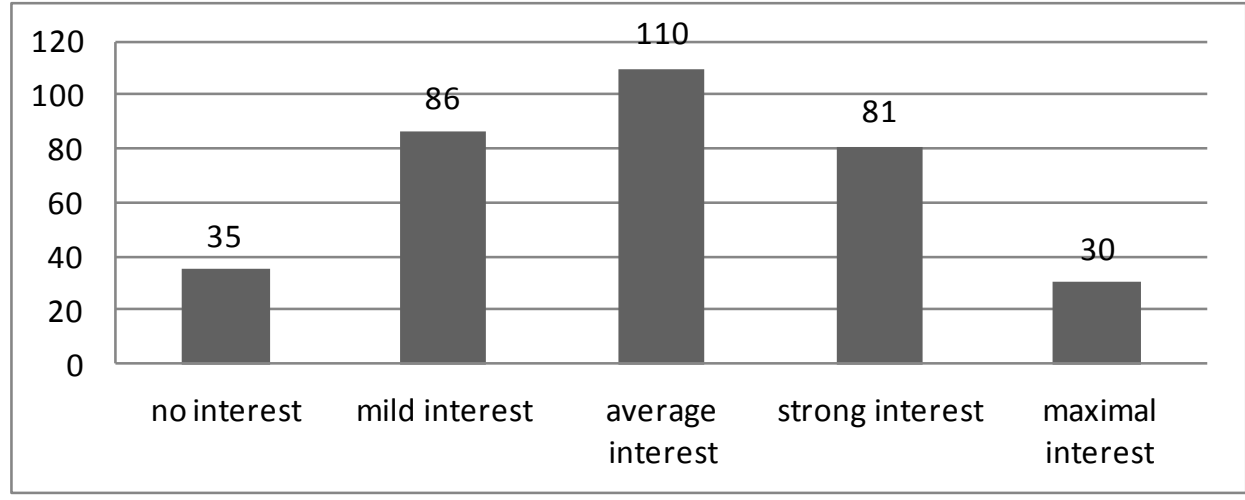

Source: own processing, 2013 
Figure 5: Level of tourists' interest in the urban architecture in the visited region

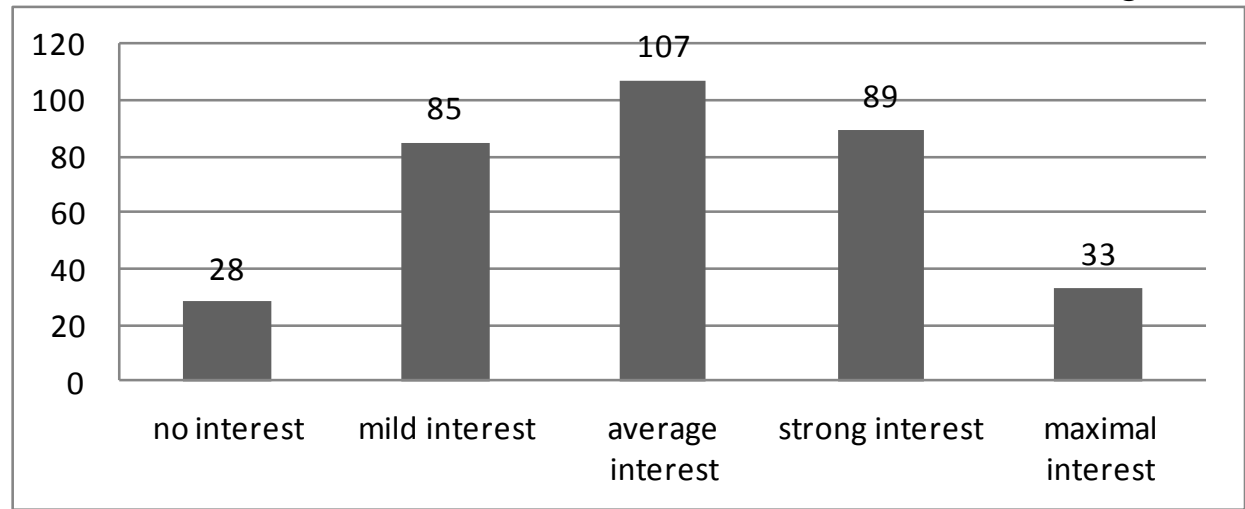

Source: own processing, 2013

Graph illustrating the tourists' interest in the urban architecture is similar to the previous situation. The highest proportion of tourists has average interest in urban architecture (107 respondents; $31.29 \%$ ).

Figure 6: Level of tourists' interest in the traditional gastronomy of the visited region

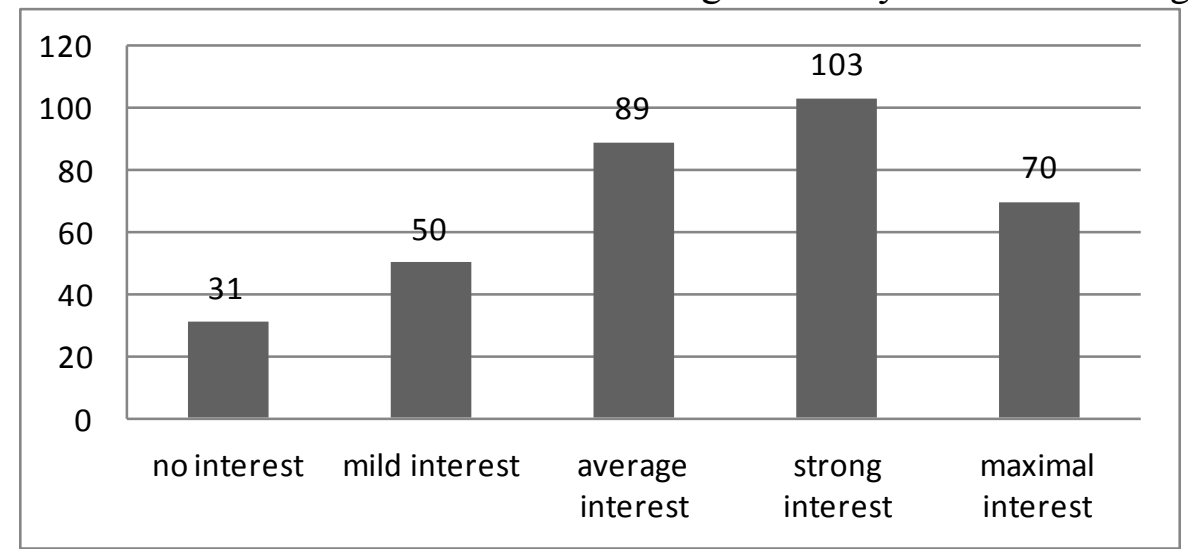

Source: own processing, 2013

Traditional gastronomy and typical regional food attract 103 respondents (30.03\%) very much, as this interest is shown as strong in this graph. 89 tourists $(25.95 \%)$ perceives it as average and 70 people $(20.41 \%)$ as maximal.

Figure 7: Presence of regional specialities on the menu of local restaurants

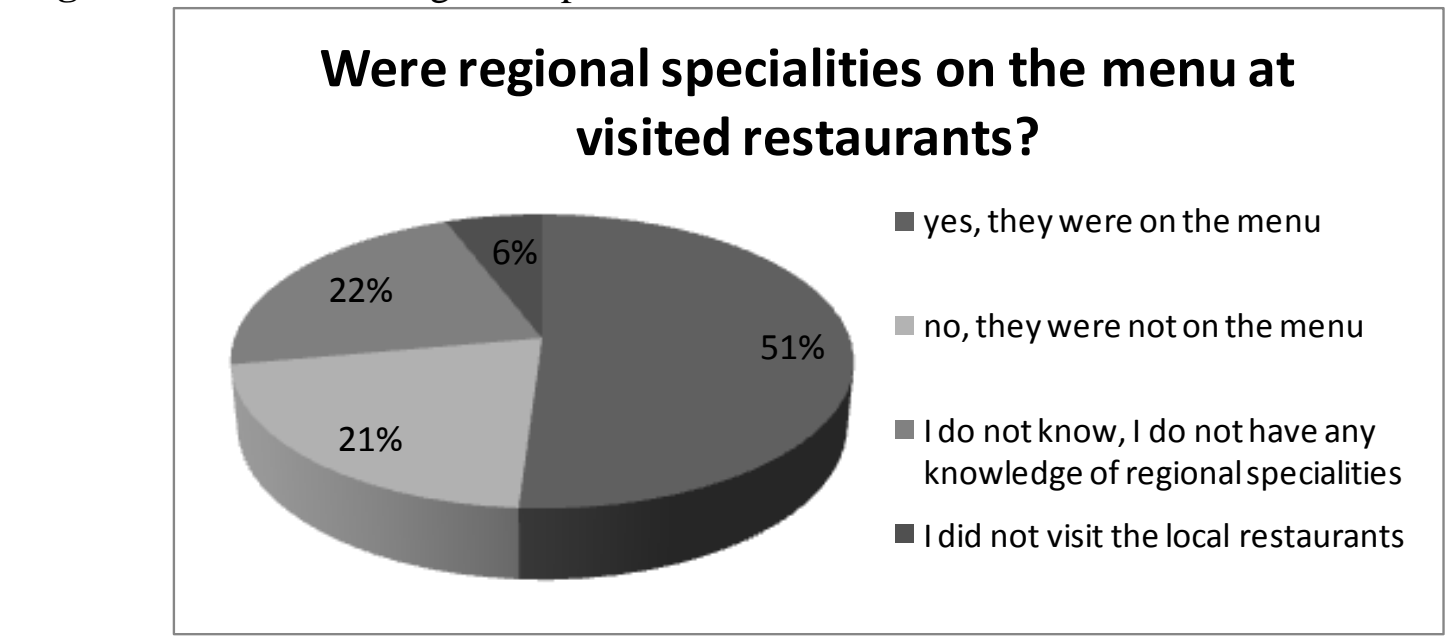

Source: own processing, 2013 
In the restaurant facilities visitors sometimes consume meals in $55.26 \%$, and almost always in $30.70 \%$, whereas $51.03 \%$ noticed the regional speciality in the offer of restaurants, $21.99 \%$ confessed that they did not have any knowledge of the regional specialities and $21.11 \%$ tourists claimed that they did not find such dishes in the assortment of the offer. The question: "Do you consider typical local food as the important part of the culture of the region?" was answered in a positive way by $38.01 \%$ of tourists, $32.46 \%$, however, concluded that there exited even more important elements and $15.79 \%$ responded in a negative way.

The Moravian-Silesian Region as an attractive tourist destination is perceived by $68.62 \%$ of tourists, however, it is not perceived that way by $1.38 \%$. Anyway it is a significant judgement.

$56.43 \%$ of women and $43.57 \%$ of men took part in the questionnaire survey, whereas the most respondents $(47.95 \%)$ belonged to the age group of $15-24$ years, $25-34$ years old respondents with the share of $17.84 \%$ participated in the questionnaire survey. In the age group of $35-44$ years $15.50 \%$ of participating took part in the survey. The age limit of $45-$ 54 years was formed by $10.82 \%$ of respondents. The lowest percentage (5.56 and 2.34) was formed by the respondents in the age of 55 - 64 years and 65 years and more.

Secondary school educated respondents participated in the proportion of $65 \%$, respondents with secondary school educated with the vocational certificate in the proportion of $12.65 \%$ and university educated respondents in the proportion of $10.29 \%$.

The economic status of the student made the highest percentage representation $(46.94 \%)$, further the status of the employee $38.78 \%$, by the share of $4.96 \%$ there were represented self-employed persons, $3.50 \%$ pensioners, and $2.33 \%$ was formed by persons in domestic services/housewives and the unemployed.

\subsection{Evaluation of hypotheses}

When reasoning out the importance of cultural tourism and regional gastronomy for the development of tourism of a certain area we start from the presumption that both of those attributes are perceived by tourists as an important part of the offer of tourism. Therefore we suppose positive responses of the more than a half of the majority of respondents to the chosen questions. In the following table there are summarized the data evaluating the set hypotheses.

Table 2: Evaluation of hypotheses

Source: own processing, 2013

\begin{tabular}{|c|c|}
\hline \multicolumn{1}{|c|}{ Hypothesis } & Result \\
\hline H1 & unconfirmed \\
\hline H2 & unconfirmed \\
\hline H3 & confirmed \\
\hline H4 & unconfirmed \\
\hline H5 & unconfirmed \\
\hline
\end{tabular}

The only one hypothesis, and that is the hypothesis no. 3, was confirmed. This hypothesis presumed that more than $60 \%$ of addressed tourists consider the Moravian-Silesian Region as the destination which is attractive for tourism. Nearly $69 \%$ from addressed respondents answered that way. 
The hypothesis no. 1 presumed that more than $60 \%$ of the addressed show at their travels "strong" up to "maximal" interest in cultural monuments, as there are castles, stately homes and similar feudal manor houses, further museums and galleries and technical monuments. This hypothesis was disproved, as "strong" up to "maximal" interest in feudal manor houses was shown by only $41.81 \%$ of respondents. In case of museums and galleries it is $39.36 \%$ of respondents and at technical monuments then only $27.41 \%$ of tourists.

The hypothesis no. 2 was not confirmed either. Compared to the supposed at least $60 \%$ of addressed tourists only roughly $48 \%$ of them would appreciate if traditional regional food was in the offer at by them visited restaurants.

The hypothesis no. 4 and 5 presumed the existence of the dependence between selected quantities. These hypotheses were verified by the method of correlation analysis within the independent research of mutual relation of cultural tourism and regional gastronomy whose complete results can be found in the article in the collection of papers from the VI. International Scientific Conference of Inceptors and young scientific workers, held by the SU OPF in November 2013 (see [5]). At verifying the hypothesis no. 4, which presumed the existence of the positive statistical relation between the number of immovable cultural monuments and the number of accessible monuments, museums and galleries in tourist areas of the region of Northern Moravia and Silesia, there was calculated the value of the correlation coefficient $(r=0,6524)$, which brought the ambiguous result. The test of the statistical significance of the correlation coefficient, however, proved that the statistical dependence does not exist between the surveyed variables. It cannot be claimed that tourist areas with a higher number of immovable cultural monuments also dispose of the higher number of accessible monuments, museums or galleries compared with tourist areas on the area of which there is smaller number of cultural immovable monuments registered in the Central List of Cultural Monuments in the CR.

The hypothesis no. 5 assumed the existence of positive dependence between the number of accessible monuments, museums and galleries and certified restaurants Czech Specials ${ }^{2}$ (that means restaurants offering traditional Czech and regional dishes). Not even this hypothesis was confirmed. The value of the correlation coefficient is close to the value of $0(r=0,1099)$, which means that between the variable does not exist the linear statistical dependence. The same result is also brought by the test of statistical significance of the correlation coefficient. From $95 \%$ thus we can claim that not even between the number of by the public accessible monuments, museums and galleries and the number of restaurants offering traditional regional dishes in the tourist areas of Northern Moravia and Silesia statistical dependence exists.

Even though the majority of set hypotheses was not proved we are convinced that regional gastronomy is a significant element of the culture of the region and plays an important role in tourism as it intensifies the authenticity of the experience from travelling and visits to destinations The combination of cultural activities and attractiveness with regional gastronomy can be anyway the base for tourist products of destinations or product packages of the particular facilities functioning in a destination.

2 CZECH SPECIALS [online]. C CzechTourism 2009 - 2013 [cit. 2013-10-16]. Available from: http://www.czechspecials.cz/. 


\section{Conclusion}

The principal objective of the paper was to describe the influence of cultural tourism and regional gastronomy on the development of tourism in the Moravian-Silesian Region. Summarized results and verification of hypotheses confirmed the perception of the MoravianSilesian Region by tourists as an attractive destination; however, they did not prove "strong" up to "maximal" interest of tourists in cultural monuments. As well the assortment offer of regional dishes was sufficient only for 48 tourists. From that it implies that Moravian and Silesian traditional gastronomy does not have so deep gastronomical roots as it is in the destination of South Moravia or South Bohemia. Our presumption on the existence of the positive dependence between the number of accessible monuments, museums and galleries and certified restaurants Czech Specials (that is restaurants offering traditional Czech and regional dishes) was not proved. Within the Concept of the state policy of tourism in the Czech Republic in the years 2014 - 2020 (prepared by the Ministry for Regional Development of the Czech Republic) and it worked out the SWOT analysis which implies unambiguously that the development of tourism in the Czech Republic is still under the level of its potential (see [8]). Foreign visitors head mainly for Prague, regions are left aside of their interest. Though the development of demand is significantly influenced by external circumstances (influencing of global trends), not a small role is also played by slow rigid reaction on the development and innovation of the offer of competitive destinations.

In the Moravian-Silesian Region it is necessary to search for the causes of this state besides historical reasons in the low cooperation between the participants of tourism and in the insufficient extent of the coordination of activities on the national and regional level as well. The example of that was empiric experience of the authors of the paper at communication in cooperating institutions, demonstrated by the mutual reluctance between some participants of the destination management to cooperate reciprocally among themselves. Finding the acceptable system of settling institutions and participants of tourism is the basic starting point for the growth of the quality of services whose complementing services are just catering services.

\section{Acknowledgement}

This paper has originated with the support of the grant SGS/26/2013: Relation of cultural tourism and regional gastronomy and their influence on the development of tourism (on the example of the Moravian-Silesian Region).

\section{References}

[1] CZECH SPECIALS [online]. C) CzechTourism 2009 - 2013 [cit. 2013-10-16]. Available from: http://www.czechspecials.cz/

[2] DUPUIS, E. M. and D. GOODMAN, 2005. Should we go „home“ to eat?: toward a reflexive politics of localism [online]. Journal of Rural Studies. 21 (3), 359-371 [cit. 2013-10-20]. ISSN 0743-0167. Available from: http://www.agroecology.wisc.edu/ courses/agroecology-702/materials/9-farm-and-comm-viability/dupuis-goodman2005.pdf

[3] HESKOVÁ, M., 2011. Cestovní ruch: pro vyšší odborné školy a vysoké školy. 2. vyd. Praha: Fortuna. ISBN 978-80-7373-107-6.

[4] HOLUB, K., 2004. Vybrané kapitoly z dějin gastronomie a hotelnictví. VŠH v Praze 8. Poděbrady: Pošík. ISBN 80-86578-16-X. 
[5] KARÁSKOVÁ, T. a A. ZEDKOVÁ, 2013. Kulturní turismus a tradiční gastronomie v turistickém regionu Severní Morava a Slezsko. In: Sbornik př́spěvků VI. mezinárodní védecká konference doktorandi̊ a mladých vědeckých pracovníkủ [CD]. Karviná: SU OPF, s. 146-156. ISBN 978-80-7248-901-5.

[6] KESNER, L., 2005. Marketing a management muzeí a památek. Praha: Grada. ISBN 80-247-1104-4.

[7] KMECO, L., 2006. Využitie kultúrného didičstva v cestovnom ruchu. Rukovät' k predmetu Dejiny kultúry. EF UMB v Banskej Bystrici. Zvolen: Bratia Sabovci, s.r.o. ISBN 80-8083-245-5.

[8] Koncepce státní politiky cestovního ruchu v České republice v letech 2014 - 2020. $M M R ~ \check{C} R$ [online]. [cit. 2014-01-02]. Available from: http://www.mmr.cz/getmedia/ dac4627c-c5d4-4344-8d38-f8de43cec24d/Koncepce-statni-politiky-cestovniho-ruchu-vCR-na-obdobi-2014-2020.pdf

[9] MALÁTEK, V., 2001. Metodologie marketingového výzkumu. SU Opava, Obchodně podnikatelská fakulta Karviná. Frýdek Místek: Kleinwächter. ISBN 80-7248-119-3.

[10] NUMMEDAL, M. and C. M. HALL, 2006. Local Food in Tourism: An Investigation Of The New Zealand South Island's Bed And Breakfast Sector's Use and Perception of Local Food. Tourism Review International [online]. 9(4), 365-378 [cit. 2013-10-20]. Available from: http://www. cabdirect.org/abstracts/20063086997.html

[11] PRATT, J., 2007. Food Values: The Local and the Authentic. Critique of Anthropology [online]. 27(3), 285-300 [cit. 2013-10-20]. Available from: http://coa.sagepub.com/content/27/3/285.abstract

[12] SHENOY, S. S., 2005. Food Tourism And The Culinary Tourist. A Thesis Presented to the Graduate School of Clemson University [online]. [cit. 2013-10-23]. Available from: http://www.torcttracanada.ca/torc/downs1/food\%20tourism\%20and\%20culinary\%20tou rism.pdf

[13] SIMS, R., 2009. Food, place and authenticity: local food and the sustainable tourism experience. Journal of Sustainable Tourism [online]. 17(3), 321-336 [cit. 23.10.2013]. Available from: http://www.tandfonline.com/doi/pdf/10.1080/09669580802359293

[14] STEIN, P. J., 1976. Single Leben in den USA der 70er Jahre. Englewood Cliffs (New Jersey): Prentice-Hall.

[15] VLASATÁ - GERYKOVÁ, Z., 2009. Luxusní stravování na počátku 21. století a jeho environmentální souvislosti. Diplomová práce. Masarykova univerzita, Fakulta sociálních studií. Vedoucí práce Hana Librová.

[16] YURTSEVEN, H. R. and O. KAYA, 2011. Local Food in Local Menus. Tourismos: An International Multidisciplinary Journal Of Tourism [online]. 6(2), 263-275 [cit. 201305-11]. Available from: http://www.chios. aegean.gr/tourism/ VOLUME _6_No2_art15.pdf 